\title{
Relasi Perempuan dan Laki-laki dalam Iklan Teh Sariwangi
}

\author{
Anisa Eka Kusuma Dewi \\ Program Studi Ilmu Komunikasi, Universitas Muhammadiyah Yogyakarta, Indonesia \\ Anisa.eka.isip19@mail.umy.ac.id \\ Anika Dwi Kusuma Dewi \\ Program Studi Ilmu Komunikasi, Universitas Muhammadiyah Yogyakarta, Indonesia \\ Anika.dwi.isip19@mail.umy.ac.id \\ Diserahkan: 29 April 202 1; Direvisi: 8 Juni 2021; Diterima: 10 Juni 2021
}

\begin{abstract}
The relationship between women and men in the family is an interesting thing to study regarding the views of gender roles and the duties of a husband and wife from most societies, especially in Indonesia today. The purpose of this research is how the relationship between women and men in SariWangi tea advertisements and seeing gender equality in family harmony? This study uses the theory of masculinity and feminism by using the semiotic method of the social production of meaning from the sign system of the Swiss linguist thinker, Ferdinand de Saussure. This analysis is carried out through advertising signs from the cut scenes regarding how gender roles represent duties and responsibilities in the family. Based on the results of the analysis, men have full control in any case so that men have dominant rights in the family where the patriarchal system is very strong held by men as the head of the household. Which means that in the family, women have minority rights that must obey whatever is decided by their husbands as the head of the family. Keywords: Family, Gender Roles, Husband and Wife, Teh Sariwangi.
\end{abstract}

\begin{abstract}
Abstrak
Relasi antara perempuan dan laki-laki dalam keluarga merupakan hal yang menarik untuk diteliti mengenai pandangan peran gender dan tugas seorang suami dan istri dari kebanyakan masyarakat terutama di Indonesia sekarang ini. Tujuan dari penelitian ini yaitu bagaimana relasi perempuan dan laki-laki dalam iklan teh SariWangi dan melihat kesetaraan gender dalam keharmonisan keluarga? Penelitian ini menggunakan teori maskulinitas dan feminisme dengan menggunakan metode semiotika mengenai produksi sosial makna dari sistem tanda dari pemikir sang pakar bahasa Swiss, Ferdinand de Saussure. Analisis ini dilakukan melalui tanda-tanda iklan dari potongan adegan-adegan tersebut mengenai bagaimana peran gender mempresentasikan tugas dan tanggung jawab dalam keluarga. Berdasarkan hasil analisis, lakilaki mempunyai kendali penuh dalam hal apapun sehingga laki-laki memiliki hak yang dominan dalam keluarga dimana sistem patriakhi sangat kuat dipegang laki-laki sebagai kepala rumahtangga. Dimana yang artinya di dalam keluarga perempuan memiliki hak minoritas yang harus menuruti apapun yang diputuskan oleh suami sebagai kepala keluarga. Kata Kunci: Keluarga, Peran gender, Suami istri, Teh Sariwangi.
\end{abstract}




\section{PENDAHULUAN}

Keluarga yang harmonis memiliki peran dimana ditandai dengan adanya keselarasan dalam pembagian hak dan kewajiban serta kebahagiaan dalam keluarga. Dalam Keluarga, seharusnya menjadi tempat paling aman, damai dan tentram bagi seluruh anggotanya. Namun faktanya, masih banyak problematika yang terjadi dalam ketidakadilan peran pembagian kerja gender antara suami dan istri. Berbagai persoalan yang terjadi dalam keluarga disebabkan oleh konstruksi sosial sejak lama dimana pada manusia zaman dahulu laki-laki dikenal sebagai pemburu/pencari makanan sedangkan wanita yang memasak hasil dari pemburuannya yang dimana dinormalisasikan sampai saat ini (Sakee, 2014).

Ada perbedaan secara biologis antara perempuan dan laki-laki, namun kebudayaan menafsirkan perbedaan biologis ini menjadi seperangkat tuntutan sosial tentang kepantasan, hak-hak dan kuasa. Contoh yang mencolok misalnya, hampir semua kelompok masyarakat menyerahkan tanggung jawab perawatan anak dan rumah pada perempuan, sedangkan dalam hal mencari nafkah atau bekerja diberikan pada laki-laki (Lady et al., 2020).

Masyarakat melihat bahwa perempuan yang memilih menjadi ibu rumah tangga (IRT) lebih baik daripada menjadi wanita karir dan stigma bahwa perempuan berkarir tidak mengutamakan jodoh atau keluarga yang dapat menghilangkan motivasi para perempuan untuk terus meraih apa yang mereka inginkan (Lady et al., 2020). Ketidakadilan kesetaraan gender nampaknya banyak juga terlihat di media iklan contohnya sepertinya iklan "Teh SariWangi" yang terbaru pada tahun 2021 dimana dalam iklan tersebut memperlihatkan sepasang suami istri yang posisinya dua-dua bekerja. Namun, sang suami mendapatkan gaji lebih besar dari sang istri, kemudian memerintah istrinya untuk berhenti bekerja. Terlihat dalam masalah tersebut seakan-akan posisi wanita (istri) lebih baik untuk mengurus rumah tangga keluarga saja dan laki-laki (suami) yang bertanggungjawab bekerja untuk menafkahi keluarga.

Dari latar belakang di atas, maka rumusan masalah penelitian ini bagaimana relasi perempuan dan laki-laki dalam iklan teh SariWangi dan melihat kesetaraan gender dalam keharmonisan keluarga?

Tujuan penelitian ini dilakukan untuk mengetahui relasi perempuan dan laki-laki dan melihat kesetaraan gender dalam keharmonisan keluarga dalam iklan teh SariWangi pada iklan tahun 2021. Dimana perempuan dicap kali hanya sebagai ibu rumah tangga dan tidak diperkenankan untuk menjadi wanita karir dan laki-laki dicap kali sebagai kepala rumah tangga atau kepala keluarga yang menjadi penguasa atau dominan di dalam keluarga. Sehingga, apabila tidak mencapai hal ini, maka perempuan yang bekerja diluar rumah akan mendapat stereotype yang negatif, sehingga terjadinya diskriminasi serta ketidakadilan yang merugikan.

Beberapa penelitian terdahulu terhadap bentuk dalam relasi perempuan dan laki-laki dalam kesetaraan gender dapat ditelaah sebagai berikut. Pertama, penelitian yang dilakukan oleh Ingesti Lady Rara Prastiwi dan Didi Rahmadanik (2020), penelitiannya melihat bahwa pengaruh budaya memegang peran penting terhadap pandangan tentang wanita karir. Contohnya dalam budaya Jawa, ada pepatah yang mengatakan bahwa perempuan hanya miliki tugas 3M. Pepatah tersebut lambat laun membentuk opini bahwa tugas seorang perempuan hanyalah berdandan, melahirkan dan mengurus anak, serta memasak. Berbicara tentang kedudukan perempuan dalam budaya Jawa berada dalam posisi di bawah laki-laki, karena dalam Budaya Jawa peran laki-laki dikonsepkan pekerja publik (luar rumah), sedangkan perempuan dikonsepkan pekerja domestik (di dalam rumah tangga). Budaya Jawa memandang perempuan tidak jauh berbeda dengan pendapat-pendapat yang beredar bahwa kaum perempuan tidak lain hanyalah seorang pelayan yang kedudukannya di bawah kaum laki-laki. Bagi masyarakat Jawa, anak perempuan harus memahami konsep unggah-ungguh (sopan santun). Perempuan harus bisa menjadi lakon yang baik dan menuruti semua perintah dari orang tuanya. Budaya patriarkis inilah yang kemudian hidup dan berperan besar untuk terus menyudutkan perempuan dengan peran gendernya. Selain mengenai sopan santun, anggapan bahwa anak 
perempuan kurang layak untuk mendapatkan hak pendidikan tinggi juga masih kental dalam masyarakat Jawa (Lady et al., 2020).

Kedua, penelitian yang dilakukan oleh Anaway Irianti Mansyur dan Dede Rahmat Hidayat (2020) dimana penelitian ini berfokus pada wanita karir dituntut untuk bersikap professional dalam sebuah pekerjaan. Namun, wanita yang memilih berkarir harus menyesuaikan dengan teknologi yang terus berkembang pesat. Dengan wanita menggabungkan peran mereka dalam pekerjaan dan sebagai ibu dan istri dalam rumah tangga, secara otomatis akan menghadapkan wanita dengan berbagai masalah, seperti: Peningkatan tanggung jawab yang menyita waktu dan menimbulkan stress fisik serta emosional, Rasa bersalah karena kurang dapat memberikan perhatian dan waktu pada anak atau pekerjaan. Sehingga dibutuhkan kesiapan mental bagi wanita yang memilih untuk berkarir (Mansyur \& Hidayat, 2020).

Berbeda dari dua penelitian diatas, penelitian terakhir ini merupakan penelitian yang dikerjakan oleh Suryani Jihad (2019). Penelitiannya ini berfokus pada bagaimana fitrah seorang perempuan terhadap karir, rumah dan pendidikan. Dimana Kesadaran akan pentingnya peranan seorang perempuan hendaknya dijadikan sebagai alasan utama agar kedududkan seorang perempuan tidak lagi dikesampingkan, melainkan dalam era sekarang ini perempuan memiliki peranan yang sangat penting. Menyadari hal tersebut, seorang perempuan hendaknya menyeimbangkan perannya dalam fitrah seorang perempuan dalam karir dimana seorang perempuan tidak ada larangan dalam mengembangkan keahliannya dan memperluas hubungan silaturahimnya baik pada orang-orang yang berbeda bangsa, suku, ataupun lawan jenis asalkan tetap berladaskan pada kaidah Islam . Fitrah seorang perempuan dalam rumah tangga yakni menyadari akan kewajibannya sebagai seorang istri dan ibu dari anak-anaknya. Dan yang terakhir yakni fitrah seorang perempuan dalam pendidikan yang dituntut untuk dimiliki, dikarenakan dengan pendidikannya, maka modal utama sebagai madrasah untuk anak-anaknya telah dikantongi dalam membesarkan dan membimbing anak-anaknya ke jalan yang senantiasa diridhoi oleh Allah SWT. Serta dengan pendidikannya seorang perempuan dapat mengembangkan keahliannya dalam berkarier dan bekerja (Jihad, 2019).

Berbeda dengan ketiga di atas yang meneliti mengenai pengaruh budaya terutama dalam budaya jawa yang memegang peran penting terhadap pandangan tentang wanita karir, kesiapan mental bagi wanita atau ibu rumah tangga yang memilih untuk berkarir dan fitrah seorang perempuan terhadap karir, rumah dan pendidikan dalam islam. Penelitian ini berfokus pada representasi dalam media iklan terhadap relasi perempuan dan laki-laki dalam iklan Teh SariWangi.

\section{KAJIAN PUSTAKA}

\section{MASKULINITAS}

Maskulinitas Gender yang secara kultural dibangun di atas tubuh laki-laki secara anatomis. Maskulinitas mendefinisikan seperangkat perilaku, bentuk ucapan, dan gaya tingkah laku yang dapat diidentifikasi yang berfungsi untuk membuat laki-laki tetap dominan dalam masyarakat patriarkal. Di sebagian besar budaya, maskulinitas adalah istilah dominan dalam oposisi biner yang menundukkan feminitas.

Semua masyarakat manusia adalah patriarkal karena mereka dipisahkan dan dikelompokkan berdasarkan jenis kelamin sehingga perempuan ditindas dalam lembaga sosial dan politik mereka membagi tenaga kerja produktif dan reproduktif berdasarkan jenis kelamin dan mendiskriminasi perempuan secara ekonomi. Mereka mengistimewakan laki-laki daripada perempuan secara umum, menjamin laki-laki dengan akses yang lebih besar. Mereka menghargai laki-laki dan maskulinitas lebih tinggi daripada perempuan dan feminitas. Dalam sistem diskursif dan simbolik dimana mereka memusatkan, membakukan, dan menormalkan subjektivitas dan sudut pandang laki-laki sementara menjadikan perempuan sebagai objek "Lainnya" (Frith \& Gates, 2010).

Perbedaan gender antara maskulinitas dan feminitas bagaimanapun ditentukan secara budaya dan bentuknya dapat sangat bervariasi dari satu konteks budaya ke konteks budaya lainnya. Kita 
disosialisasikan ke dalam pola dan hubungan identitas gender yang berbeda sesuai dengan aturan budaya dan kode situasi sosial dan sejarah kita. Proses ini tidak ditentukan secara alami, dan patriarki menjelaskan fakta bahwa di sebagian besar masyarakat dan budaya yang dikenal, laki-laki memiliki lebih banyak kekuasaan dan otoritas daripada wanita, dan menjalankan kekuasaan atas wanita. Seperti yang dikemukakan oleh banyak penulis feminis, patriarki bukan sekadar sistem perbedaan antara lakilaki dan perempuan, perbedaan ini diatur dalam hubungan terstruktur subordinasi dan dominasi yang secara historis direproduksi dari generasi ke generasi. Akibatnya, sering dianggap bahwa posisi sosial dan kekuasaan laki-laki dan perempuan ditentukan secara biologis misalnya seperti menganggap 'wajar' bagi laki-laki untuk mendominasi dan menegaskan dan mengaggap 'wajar' bagi perempuan untuk menjadi pasif atau emosional.

Dengan demikian, hal tersebut merupakan dominasi struktural, sistematis dan historis dimana eksploitasi perempuan oleh laki-laki. Dalam penggunaan aslinya, istilah ini merujuk secara sempit pada jenis suku, kelompok, keluarga atau rumah tangga tertentu yang dicirikan oleh penguasa lakilaki yang dominan, sang patriarki, yang mengambil alih kekuasaan yang menentukan atas kelompok tersebut dan hubungan sosialnya. Dalam kasus keluarga dan kelompok rumah tangga, patriarki menggabungkan kekuasaan ayah dengan anggota laki-laki yang dominan. Konsep tersebut sekarang lebih luas dan secara umum digunakan untuk merujuk pada total organisasi sosial dari relasi gender, institusi dan proses sosial yang menghasilkan dan mereproduksi perempuan sebagai bawahan laki-laki secara sosial, politik dan seksual.

Banyak penulis berpendapat bahwa perempuan di negara-negara kapitalis 'dirugikan dua kali lipat' oleh struktur dan keterkaitan antara sistem patriarkaki dan sistem kapitalis. Kegiatan memproduksi dan mempertahankan kritik terpadu terhadap patriarki dalam segala bentuknya telah menjadi usaha gerakan perempuan dan feminisme. Perjuangan ini bertujuan untuk membangun hubungan baru yang radikal antara laki-laki dan perempuan dan untuk mengubah hubungan sosial produksi dan kekuasaan politik. Tantangan ini harus dihadapi dengan cara-cara dimana hubungan patriarki diproduksi dan direproduksi dalam proses komunikasi, budaya dan kelembagaan (Saarni et al., 1983).

\section{FEMINISME}

Menurut Betty Friedan dalam buku Key Themes in Media Theory. Ia menulis buku berjudul The Feminine Mystique yang diterbitkan pertama kali pada 1963 sekitar 15 tahun setalah perang dunia kedua di Amerika Serikat (sekitar 1945-1960), ketika 'ibu rumah tangga pinggiran kota' menjadi citacita feminin yang menjadi dasar orang Amerika. wanita diharapkan membangun kehidupan mereka. 'Pahlawan ibu rumah tangga yang bahagia' ini adalah sebuah mitos yang diabadikan oleh media dan diterima secara sosial sebagai 'citra barang wanita. Sejak usia muda, wanita diharapkan untuk mengorbankan karir, kemandirian, keterampilan dan kualifikasi mereka untuk kepentingan 'keluarga inti' mereka (Laughey, 2007).

Feminisme dapat dipahami baik sebagai beragam karya teoritis dan sebagai gerakan sosial dan politik. Dalam kedua kasus tersebut, feminisme berusaha untuk memeriksa posisi perempuan dalam masyarakat dan untuk memajukan kepentingan mereka. Feminisme memiliki pengaruh besar dalam studi budaya dan memang mereka memiliki pandangan yang sama bahwa produksi pengetahuan bersifat politis dan posisional bersama dengan keinginan untuk terlibat dengan, atau menjadi bagian dari gerakan politik di luar akademi.

Secara umum, feminisme menegaskan bahwa seks adalah poros yang fundamental dan tidak dapat direduksi organisasi sosial yang sampai saat ini telah mensubordinasikan perempuan ke laki-laki. Jadi, feminisme secara sentral berkaitan dengan seks sebagai prinsip pengorganisasian kehidupan sosial yang benar-benar jenuh dengan hubungan kekuasaan. Kebanyakan feminis berpendapat demikian bahwa subordinasi perempuan terjadi di seluruh jajaran institusi sosial dan praktik dengan tingkat keteraturan yang menjadikannya fenomena struktural. Ini subordinasi struktural perempuan telah 
digambarkan oleh feminis sebagai patriarki dengan arti turunannya dari keluarga kepala laki-laki, penguasaan dan keunggulan (Alva Orlandini, 2003).

Kelompok feminis berpendapat bahwa keluarga adalah sumber eksploitasi khususnya bagi kaum perempuan. Pembagian kerja dan peran dalam keluarga menurut pandangan kelompok ini terjadi secara tidak adil dan tidak proposional, sehingga relasi gender menjadi timpang. Pembagian kerja tersebut umumnya dilandasi oleh idiologi partriarki. Melalui proses yang panjang dan bias “ kepentingan" laki-laki, maka pembagian kerja dan peran di dalam keluarga, cenderung mempunyai beban yang tidak seimbang. Perempuan biasanya ditempatkan pada posisi yang harus menjalankan peran dan tanggung jawab yang berkaitan dengan pekerjaan domestik dan laki-laki pada sektor publik. Pembagian kerja seperti ini sepintas kelihatan ringan, akan tetapi dalam prakteknya menyebabkan kaum perempuan harus bekerja dengan jam yang lebih panjang dibandingkan dengan kaum laki-laki. Lebih lanjut yang terjadi bukan pembagian kerja dan peran antara laki-laki dan perempuan, tetapi berkembang dan terus menerus dikontruksi secara sosial budaya adalah perbedaan antara laki-laki dan perempuan (Aisyah, 2014).

\section{METODE PENELITIAN}

Penelitian ini berusaha menjawab rumusan masalah tentang relasi perempuan dan laki-laki dalam iklan Teh Sariwangi. Untuk mendapatkan jawaban berdasarkan rumusan masalah pada penelitian ini digunakan metode semiotika. Semiotika merupakan studi mengenai produksi sosial makna dari sistem tanda dan ilmu yang menganalisis kehidupan tanda-tanda pada masyarakat dalam sebuah buku yang diluncurkan pada tahun 1916 oleh Ferdinand de Saussure. Gagasannya tersebut dikembangkan oleh pemikir strukturalis Prancis bernama Roland Barthes, yang kemudian mempopulerkan dan memperluas semiotika pada tahun 1960-an.

Semiotika berkisar di sekitar studi tentang tanda dalam teks. Tanda (sign) terdiri dari dua aspek yaitu Signifikan (penanda) dan Signified (petanda). Penanda dapat diartikan sebagai bentuk atau fisik. Penanda bisa berupa suara, gambar, huruf, gambar dan sejenisnya. Sedangkan petanda adalah konsep atau makna dari apa yang ditandai. Hubungan keduanya bersifat "sewenang-wenang" (arbitary), yang artinya tidak ada hubungan yang sifatnya wajar antara penanda dan petanda (Hartley, 2003).

Saussure mengklaim bahwa setiap karakter (kata) dalam sistem bahasa terkait erat dengan sistem secara keseluruhan. Satu kata "Konten hanya dibuat dengan persetujuan semua orang di sekitarnya". Untuk menggambarkan hal ini, Saussure membedakan antara bahasa (sistem atau struktur keseluruhan) dan bebas bersyarat (bahasa khusus dalam sistem itu) dari bahasa tertentu. Sebuah ucapan (bebas bersyarat) hanya dapat secara efektif berarti makna dalam hubungannya dengan seluruh sistem bahasa (Laughey, 2007).

Dengan dilanjutkannya mitos dari Roland Barthes, yang memperluas teori Saussure tentang sistem bahasa dengan menerapkannya pada sistem di mana masyarakat dan budaya mengembangkan "mitos". Dipercaya bahwa masyarakat dan budaya, seperti bahasa, disusun oleh sistem "keseluruhan" yang mendefinisikan bagian-bagiannya masing-masing. Bahasa sebagai suatu sistem juga menjadi dasar bagi kelangsungan hidup masyarakat atau kebudayaan. Namun, Barthes mengklaim bahwa makna linguistik murni diubah secara radikal oleh praktik sosial dan budaya (Laughey, 2007).

Ide yang diungkapkan Barthes terkait dengan mitos tersebut. Dalam arti konotatif yang dalam, pemikiran Popular Culture Texts Barthes merupakan kelanjutan dari asumsi Saussure tentang hubungan antara bahasa yang ditandakan atau antara penanda dan sinyal. Dengan demikian, pemikiran yang dikembangkan oleh Barthes dengan memperluas warisan pemikiran Saussure dengan meruntuhkan praktik tanda pada tingkat konotasi tanda. Konotasi bagi Barthes sebenarnya menunjukkan apa yang disebutnya mitos. Yang perlu dipahami adalah bahwa mitos ini berkonotasi dengan ideologi tertentu. 


\begin{tabular}{|l|l|}
\hline $\begin{array}{l}\text { 1. Penanda } \\
\text { rambu jalan lingkaran merah yang } \\
\text { tengahnya ada strip putih }\end{array}$ & $\begin{array}{l}\text { 2. Petanda } \\
\text { rambu dilarang } \\
\text { masuk }\end{array}$ \\
\hline $\begin{array}{l}\text { 3. Tanda } \\
\text { rambu dilarang masuk }\end{array}$ & $\begin{array}{l}\text { II. PETANDA } \\
\text { Larangan masuk } \\
\text { bagi kendaraan } \\
\text { bermotor dan tidak } \\
\text { bermotor }\end{array}$ \\
\hline $\begin{array}{l}\text { III. TANDA } \\
\text { Bagi pengendara motor dan mobil jika melihat rambu dilarang masuk tidak } \\
\text { diperbolehkan masuk ke daerah tertentu yang terdapat rambu tersebut. }\end{array}$ \\
\hline
\end{tabular}

Gambar 1. Semiotika Model Roland Barthes

Sumber: Roland Barthes (dalam Storey, 1994)

Dalam penelitian ini semiotika dilakukan dengan menelaah karakter-karakter yang terdapat pada iklan Teh Sariwangi. Iklan Teh Sariwangi diposisikan sebagai teks yang terdiri dari karakter yang berbeda. Karakter yang hadir dalam bentuk gambar, teks atau suara berasal dari rekaman dan adegan pada iklan Teh Sariwangi. Pada tahap hasil penelitian, peneliti akan menyajikan makna denotatif dan konotatif, dilanjutkan dengan pembahasan di mana intertekstualitas hasil penelitian tersebut dianalisis dengan berbagai teori yang relevan.

\section{HASIL DAN PEMBAHASAN}

HASIL

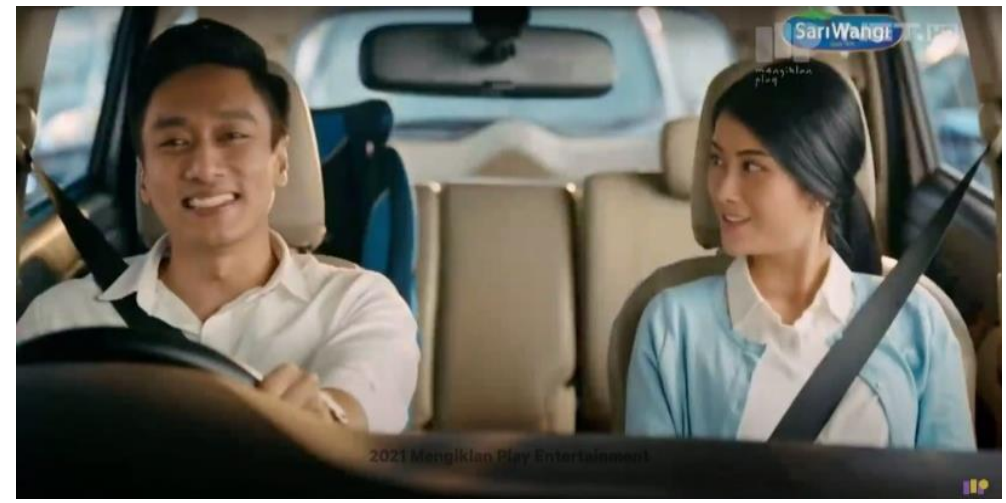

Gambar 2. Tangkapan layar Scene 1 Iklan Teh Sariwangi

(Sumber: YouTube)

Makna Denotasi: Dapat diuraikan, petanda yang berada dalam potongan gambar 1 dalam iklan di atas ialah terdapat pasangan suami istri berada di dalam mobil dimana sang suami sedang fokus menyetir. Terlihat Keduanya menggunakan seatbelt dimana sang suami mengenakan pakaian kemeja putih dan sang istri mengenakan pakaian berwarrna biru. Sembari menyetir, sang suami memberitahukan kepada sang istri bahwa ia telah mendaptkan gaji yang besar dengan mengatakan "mama bisa berhenti kerja, gaji papa naik besar". Hal ini menunjukkan bahwa sang suami sebagai kepala rumah tangga merasa paling bertanggung jawab bekerja untuk menafkahi keluarga ditambah lagi dengan raut wajah yang terlihat senang dan tenang karena gajinya telah naik besar sehingga dengan penghasilannya tersebut dirasa sudah cukup untuk memenuhi kebutuhan keluarga, tanpa harus dibantu dari sang istri dimana juga sebagai seorang pekerja. 
Makna Konotasi: laki-laki (suami) sebagai kepala keluarga memiliki tanggung jawab penuh bekerja untuk menafkahi keluarga.

Screenshot dalam iklan ini menampilkan makna dengan menganggap bahwa sebagai laki-laki (suami) mempunyai kendali penuh dalam hal mencari nafkah untuk keluarga. Dengan hal itu, secara tidak langsung memposisikan laki-laki mempunyai pengaruh besar terhadap keluarga karena suami memiliki peran sebagai kepala keluarga serta tulang punggung keluarga dimana merasa memiliki beban dan tanggung jawab yang besar terhadap keluarga. Di dalam gambar iklan tersebut menunjukkan bahwa saat berkendera dalam tugas menyetir biasanya diserahkan kepada laki-laki. Hal ini dikarenakan bahwa laki-laki menyukai hal mengenai otomotif mobil dan pada saat berkendara lakilaki cenderung tenang dan memiliki emosi yang stabil daripada perempuan yang cendurung kurang bisa mengendalikan emosi pada saat berkendara.

Mitos: laki-laki (suami) sebagai kepala keluarga memiliki tanggung jawab penuh bekerja untuk menafkahi keluarga menjadikannya penguasa atau dominan di dalam keluarga.

Keluarga dimana sistem patriakhi sangat kuat dipegang biasanya pembagian kerja dan peran dominan dipegang laki-laki sebagai kepala rumahtangga. Laki-laki sebagai pemimpin didorong untuk memiliki pendidikan yang lebih tinggi dibandingkan perempuan. Di satu sisi laki-laki dituntut untuk mencari nafkah yang harus dapat memenuhi kebutuhan anak anak dan istrinya (Utamidewi, 2017). Hal ini dikarenakan dari hasil konstrruksi sosial dan dalam islam juga mengatakan bahwa laki-laki diidentikan sebagai pemimpin. Dengan itu, laki-laki memiliki dominan di beberapa bidang termasuk di dalam keluarga dan ini telah di normalisasikan sejak lama oleh masyarakat luas. Sehingga sebagai kepala keluarga, segala sesuatunya yang terkait dalam kepengurusan rumah tangga itu diatur oleh sang suami.

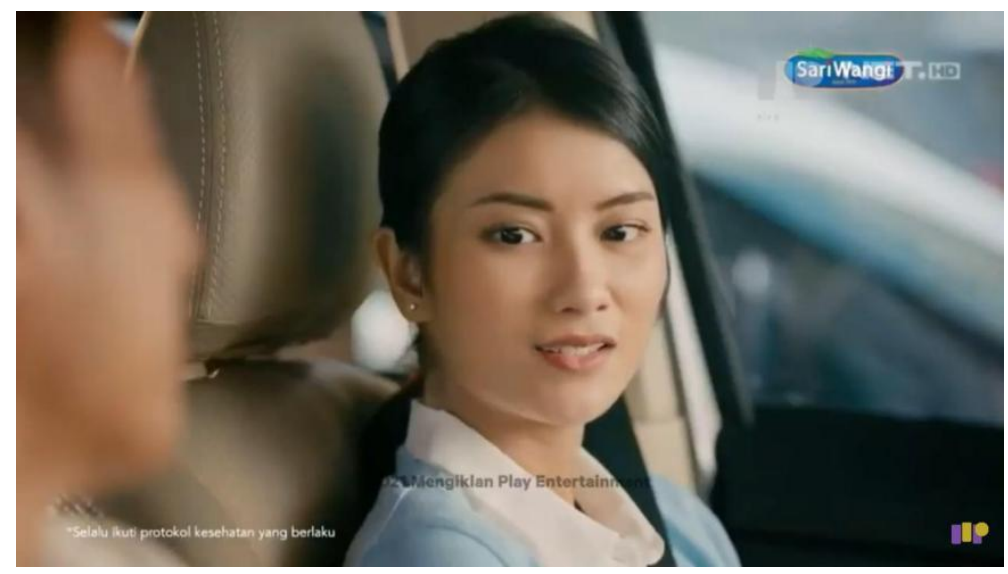

Gambar 3. Tangkapan layar Scene 2 Iklan Teh Sariwangi

Sumber: YouTube

Makna Denotasi: Petanda yang berada dalam potongan gambar 2 dari iklan di atas ialah terdapat sepasang suami istri yang sedang mengobrol di mobil. Terlihat sang istri mengenakan pakaian berwarrna biru, dengan latar ruangan dalam mobil dan menggunakan seatbelt. Dari raut wajah sang istri terlihat sedih dan kedua mata menghadap kebawah, hal tersebut karena mendengar perkataan sang suami dengan mengatakan "mama bisa berhenti kerja, gaji papa naik besar" menandakan sang istri sedang merasakan rasa kekecewaan, sedih, dan tidak percaya diri.

Makna Konotasi: perempuan terlihat tidak dihargai dan merasa rendah.

Dari iklan diatas menampilkan makna, bahwa perempuan dikonotasikan sebagai manusia lemah lembut, feminim, ibu rumah tangga, tak berdaya, dan lain-lain. Terlihat dari iklan tersebut bahwa sang 
suami menyuruh sang istri untuk berhenti kerja, dikarenakan gaji yang ia dapatkan lebih besar dari istrinya. Ini menandakan bahwa sebagian besar wanita hanya boleh menjadi ibu rumah tangga saja, hal ini dinormalisasikan masyarakat luas. Perempuan yang ingin berusaha sama seperti laki-laki lakukan cenderung tidak dihargai atau didukung. Hal ini dikarenakan perempuan yang melahirkan, dan fisik tidak sekuat laki-laki, yang sebaiknya hanya mengurus anak dan urusan rumah yang pekerjaannya lebih ringan. Hal ini terjadi karena kurangnya pemahaman tentang kesetaraan gender antara laki-laki dan perempuan.

Mitos: perempuan terlihat tidak dihargai dan rendah hanya akan menjadikan sebagai ibu rumah tangga. Perempuan ditunjuk Tuhan sebagai manusia yang melahirkan anak. Hal ini justru menjadi hal yang menyimpang di kehidupan sosial. Perempuan dan laki-laki sama-sama manusia, tetapi memiliki tugas yang berbeda dari pandangan masyarakat luas. Dimana laki-laki memiliki sumbangsih mencari nafkah, dan urusan pekerjaan berat. Sedangkan perempuan, sebagai ibu rumah tangga, yang hanya dapat mengurus anak dan urusan rumah karena pekerjaan yang lebih ringan jika dibandingkan laki-laki.

Dalam buku Sex and Gender yang ditulis oleh Hilary M. Lips mengartikan Gender sebagai harapan-harapan budaya terhadap laki-laki dan perempuan. Misalnya; perempuan dikenal dengan lemah lembut, cantik, emosional dan keibuan. Sementara laki-laki dianggap kuat, rasional, jantan dan perkasa. Ciri-ciridari sifat itu merupakan sifat yang dapat dipertukarkan, misalnya ada laki-laki yang lemah lembut, ada perempuan yang kuat, rasional dan perkasa. Perubahan ciri dari sifat-sifat tersebut dapat terjadi dari waktu ke waktu dan dari tempat ke tempat yang lain (Mansour Fakih, 1999) (Utamidewi, 2017).

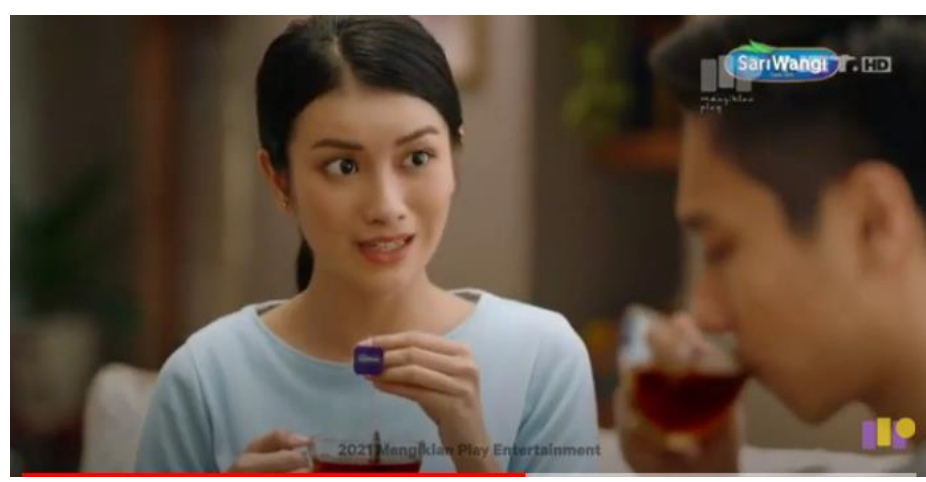

Gambar 4. Tangkapan layar Scene 3 Iklan Teh Sariwangi

Sumber: YouTube

Makna Denotasi: Pada tangkapan layar iklan diatas, tanda yang terlihat yaitu sepasang kekasih suami istri yang sedang mengobrol di ruang tamu sambil menyuguhkan secangkir teh SariWangi hangat dengan dimulai percakapan dari sang istri kepada sang suami dengan berkata "kalau mama tetap kerja gimana?" pada scene ini terlihat jelas, bahwa sang istri membujuk sang suami dengan ekspresi wajah yang takut, cemas, dan kebingungan. Sedangkan sang suami yang sedang meminum secangkir teh sambil mendengarkan percakapan istrinya.

\section{Makna Konotasi: Perempuan sebagai ibu rumah tangga memiliki harapan besar terhadap sesuatu.}

Iklan diatas terlihat bahwa sang istri yang melayani suami dengan membuat teh dan mempersilahkan suami minum terlebih dahulu, yang menandakan bahwa segala sesuatu harus dimulai dari laki-laki (suami). Dan terlihat juga sang istri yang sedang membujuk suaminya agar dapat berkerja kembali. Ia 
yakin bahwa walaupun sebagai ibu rumah tangga ia pun juga merasa mampu sebagai wanita karir. Hal ini menandakan bahwa perempuan yang sudah berumah tangga mengharapkan sesuatu besar yang akan terjadi pada dirinya, walaupun hasilnya harus bertolak belakang dengan ekspetasi yang diinginkannya.

\section{Mitos: Perempuan sebagai ibu berumah tangga juga mampu menjadi wanita karir.}

Perbedaan gender ini membuat salah satu diantaranya ada yang direndahkan, yaitu Perempuan. Hal ini menjadi hal yang normal, sekalipun perempuan itu sendiri. perempuan dicap kali harus bisa mengerjakan pekerjaan rumah sedari kecil, agar terlatih saat sudah menikah yang mana, hanya melayani suami, mengurus anak, dan mengerjakan urusan rumah. Padahal faktanya, perempuan mampu menjadi wanita karir sama seperti laki-laki. Perempua juga manusia sama seperti laki-laki, yang juga memiliki harapan terhadap pilihannya. Menjadi wanita karir, bukan berarti tidak bisa menjadi istri yang baik dalam rumah tangga. Perempuan dapat membagi waktu untuk berkerja dan menjadi istri pada saat di rumah. Namun sayangnya, mayoritas masyarakat tidak sepenuhnya menanggapi hal itu, karena terjadi kontruksi sosial sejak zaman dahulu, yang mana laki-laki dominan dari perempuan.

Kekuasaan laki laki untuk menentukan dan mengambil keputusan. Kondisi ini dianggap wajar karena dikaitkan dengan pembagian kerjaberdasarkan seks. Keberadaan budaya ini telah memberikan keistimewaan pada jenis kelamin laki-laki. Oleh karena itu budaya ini tidak mengakomodasi kesetaraan dan keseimbangan, dimana dalam budaya ini jenis kelamin perempuan tidak diperhitungkan. Budaya inilah yang kemudian yang mewujudkan garis keturunan berdasarkan garis lak-laki. Budaya patriarki ini mempengaruhi kondisi hubungan perempuan dan laki-laki, yang pada umumnya memperlihatkan hubungan subordinasi, hubungan atas-bawah dengan dominasi laki-laki (Utamidewi, 2017).

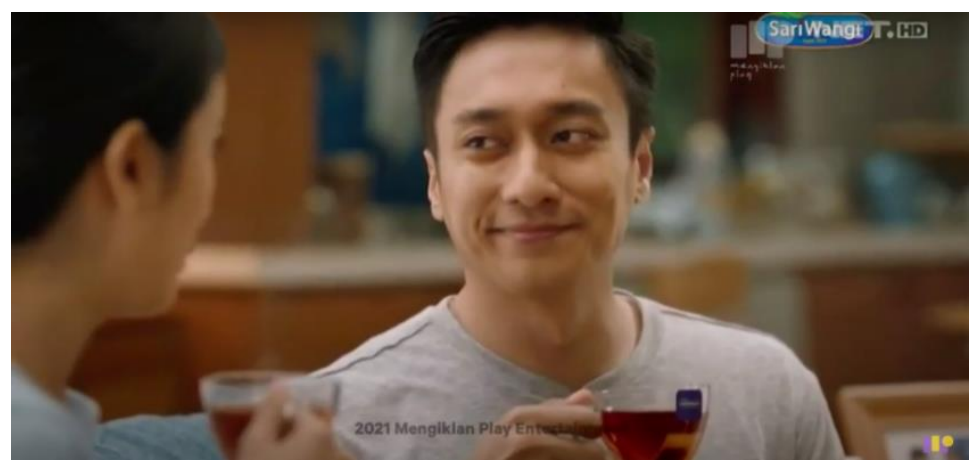

Gambar 5. Tangkapan layar Scene 4 Iklan Teh Sariwangi

Sumber: Youtube

Makna Denotasi: Pada petanda yang berada dalam potongan dalam iklan di atas terlihat sepasang suami istri sedang berdiskusi terkait negosiasi dari sang istri mengenai keinginannya untuk tetap bekerja dengan tujuan membantu demi anak dan keluarganya. Pada awalnya sang suami enggan untuk menyetujui keinginan sang istri karena memiliki rasa takut bahwa istrinya tidak bisa mengurusi segala sesuatunya dengan baik jika memiliki pekerjaan ganda namun, dengan seteguk teh SariWangi, sang suami langsung menghela napas dan merasakan nikmat hangat dari Teh SariWangi. Kemudian, pikiran dan beban yang membuatnya takut terhadap keinginannya istrinya tersebut seketika mereda dan langsung memberi keputusan dengan menyetujui keinginan sang istri untuk tetap bekerja.

Makna Konotasi: Perempuan sebagai istri, dalam negosiasi dengan laki-laki yang menjadi suaminya dinormalisasi harus mengalah. 
Di dalam rumah tangga komunikasi sangat penting untuk terus dilakukan apalagi masalah mengenai iklan dari sepasang suami istri di atas. Berdiskusi juga harus memperhatikan waktu dan suasana yang tepat untuk membicarakannya agar mendapatkan hasil keputusan yang bijak. Iklan tersebut menunjukkan bahwa segala sesuatunya perlu dikomunikasikan dimana sang istri tetap harus meminta izin mengenai keinginannya untuk tetap kerja kepada sang suami sebagai pemimpin keluarga karena hasil akhir segala sesuatunya berada ditangannya. Iklan tersebut menunjukkan bahwa berdiskusi dengan Secangkir Teh SariWangi merupakan suasana yang tepat untuk mengambil keputusan karena terlihat sang suami langsung menyetujui permintaan sang istri untuk tetap bekerja karena tujuan dari sang istri yang begitu mulia yaitu ingin membantu demi anak dan keluarga.

\section{Mitos: Perempuan sebagai istri, dalam negosiasi dengan laki-laki yang menjadi suaminya dinormalisasi harus mengalah.}

Hal ini dikarenakan perempuan dalam rumah tangga berada di bawah laki-laki. Pada akhirnya sang suami menyetujui keinginan sang istri untuk tetap bekerja. Hal ini dapat menyadarkan bahwa sang suami juga harus menghargai keinginannya sang istri, karena suami yang bijak adalah suami yang tidak membatasi hak dengan memberikan ruang untuk sang istri. Komunikasi dan suasana yang tepat merupakan elemen yang penting untuk mendapatkan sebuah keputusan. Meminum secangkir Teh SariWangi diidentikan sebagai suasana untuk mendapatkan hasil keputusan yang tepat. SariWangi percaya secangkir teh hadir sebagai fasilitator bagi keluarga Indonesia dalam mengungkapkan isi hati dengan bertatap muka langsung dapat membuat suasana menjadi lebih hangat dan tenang keharmonisan (Wuisan et al., 2018). Hal ini tidak hanya berlaku untuk sepasang suami istri seperti iklan diatas saja, namun berlaku untuk semua yang ingin berdiskusi akan suatu hal. Hal terpenting adalah jangan terlalu khawatir untuk hasil akhirnya namun yang harus dilakukan adalah berani untuk memulai berbicara dan optimis untuk mendapatkan keputusan sesuai dengan keinginan.

\section{PEMBAHASAN}

Dalam sebuah rumah tangga relasi suami dan istri sangat menentukan keharmonisan keluarga. Relasi suami dan istri yang sehat adalah bilamana suami dan istri dapat memainkan peran dan tanggungjawab masing masing. Tidak dapat dipungkiri keluarga sebagai kelompok terkecil di masyarakat juga menuntut adanya pembagian tugas dan peran antara suami istri hingga anakanaknya. Peran suami dan istri tidak lepas dari sebuah konstruksi budaya yang memberi pengaruh sangat kuat. Mayoritas daerah di Indonesia memegang sistem patriakhi yang didefinisikan sebagai suatu sistem yang bercirikan laki-laki. Pada sistem ini laki-laki memiliki kedudukan lebih tinggi daripada perempuan.

Pada sistem patriakhi ini pula kekuasaan laki laki untuk menentukan dan mengambil keputusan. Kondisi ini dianggap wajar karena dikaitkan dengan pembagian kerja berdasarkan seks. Keberadaan budaya ini telah memberikan keistimewaan pada jenis kelamin laki-laki. Oleh karena itu, budaya ini tidak mengakomodasi kesetaraan dan keseimbangan, dimana dalam budaya ini jenis kelamin perempuan tidak diperhitungkan. Budaya patriarki ini mempengaruhi kondisi hubungan perempuan dan laki-laki, yang pada umumnya memperlihatkan hubungan subordinasi, hubungan atas-bawah dengan dominasi laki-laki (Utamidewi, 2017).

Tugas utama iklan adalah untuk mengubah sebuah produk menjadi sebuah citra, dan apapun pencitraan yang digunakan dalam sebuah iklan, baik itu citra kelas sosial, citra seksualitas, dan sebagainya, yang terpenting pencitraan itu memiliki efek terhadap produk dan akan menambah nilai ekonomisnya (Bungin, 2008:126). Dalam iklan Teh SariWangi lebih banyak menggunakan citra seksualitas yang bertema keluarga karena memang produk yang dipasarkan adalah produk rumah tangga yang dikonsumsi sehari-hari dengan sering menonjolkan isi cerita mengenai masalah yang menggambarkan peran suami-istri dalam menyelesaikan sebuah permasalahan dalam rumah tangga di kehidupan sehari-hari. 
Hal ini dituangkan dalam iklan Sari Wangi dengan versi "Mari Bicara" dimana mempersepsikan isi iklan dengan mencerminkan situasi rumah tangga pada umumnya di Indonesia dimana kesalahpahaman antara pasangan suami-istri dapat diselesaikan melalui dialog. Ketika muncul sebuah persoalan dalam keluarga maka perlu mendiskusikan persoalan tersebut bersama untuk saling memahamkan dan mencari solusi. Karena di dalam keluarga, perempuan juga tetap harus berjuang sendiri untuk mengambil hak-haknya berpendapat.

Berdiskusi dengan meminum secangkir Teh SariWangi merupakan solusi yang tepat untuk mendaptakan keputusan karena fakta utama dari teh adalah minuman ringan terfavorit kedua di dunia, setelah air. Jika diminum secara rutin, teh dapat mebantu meningkatkan fungsi pembuluh darah, memerangi kepenatan, mengurangi kadar kolesterol, dan meningkatkan rasa bugar dalam tubuh (Wuisan et al., 2018). Iklan Teh Sariwangi tersebut menjelaskan berdasarkan pembahasan dalam jurnal Penggambaran Peran Suami Istri dalam Iklan The Sariwangi (Wiludjeng, Habsjah, Wibawa, 2005 , p. 3.) dimana memperlihatkan interaksi antara suami-istri dalam iklannya, yang mana tidak terlepas dari peran gender yaitu laki-laki dan perempuan. Peran antara kedua tersebut diperkuat setelah menikah dalam ajaran agama dan undang-undang yang dibuat oleh pemerintah.

Pada agama islam terdapat pembagian peran dan norma-norma yang telah tercantum dalam ayatayat Al' Quran. Di mana suami berkewajiban memimpin istri, menafkahi keluarga, melindungi keluarga dari api neraka. Sedangkan, istri berkewajiban menjadi istri yang saleh, mengerjakan tugas rumah tangga, dan tidak boleh mencari peran diluar rumah tanpa seijin suami. Hal tersebut sudah dinormalisasikan oleh masyarakat Indonesia, karena pada umumnya istri sebagai pengurus keperluan rumah tangga dan melayani suami.. Hal tersebut didukung dengan persepsi terhadap figur istri sebagai pembuat teh pada iklan diatas dianggap sesuai dengan kondisi keluarga Indonesia pada umumnya, karena istri dipersepsikan sebagai pengurus keperluan rumah tangga dan melayani suami (Keras \& Curhat, 2006). Praktek penandaan yang ada dalam iklan ini menunjukan adanya oposisi biner sebagai berikut.

Tabel 1. Oposisi Biner Relasi Laki-laki dan Perempuan dalam Iklan The Sariwangi

\begin{tabular}{|l|l|}
\hline Laki-laki & Perempuan \\
\hline Kepala rumah tangga & Anggota rumah tangga \\
\hline Berkarier & Di rumah saja \\
\hline Wilayah publik & Wilayah domestik \\
\hline Dilayani & Melayani \\
\hline Pemimpin & Dipimpin \\
\hline
\end{tabular}

\section{KESIMPULAN}

Dari hasil penelitian, dapat disimpulkan bahwa iklan Teh Sariwangi memrepresentasi peran suamiistri dalam pembagian peran yang dilakukan oleh suami-istri berdasarkan hak dan kewajiban masingmasing. Di mana hampir semua kelompok masyarakat menyerahkan tanggung jawab perawatan anak dan rumah pada perempuan, sedangkan dalam hal mencari nafkah atau bekerja diberikan pada lakilaki. Sehingga, apabila tidak mencapai hal ini, maka akan mendapat stereotype yang negatif dari masyarakat, sehingga terjadinya diskriminasi serta ketidakadilan yang merugikan. Sehingga dalam iklan Teh Sariwangi mempresentasikan peran dan kewajiaban dari kebanyakan suami dan istri lakukan di dalam rumah tangga.

Peran suami istri yang terlihat dalam iklan ini juga menunjukkan peran-peran gender berdasrakan sifat maskulinitas dan feminisme yang dimiliki. Peran suami yang dilihat berdasarkan hak dan kewajban di atas semakin memperkuat ideologi partiarki yang menjunjung tinggi laki-laki. Laki-laki mendominasi perempuan dalam segala hal sehingga pembakuan peran berdasarkan jenis kelamin ini berdampak pada pembakuan peran secara gender dimana ini akan berpengaruh pada pembagian kerja 
dalam masyarakat, pembagian kekuasaan, hak dan tanggung jawab, hubungan perempuan dan lakilaki baik dalam keluarga maupun masyarakat.

\section{PERSANTUNAN}

Terima kasih kepada Dr. Fajar Junaedi yang telah membimbing proses riset jurnal mengenai relasi perempuan dan laki-laki dalam iklan Teh Sariwangi dalam mata kuliah Kajian Kritis Iklan di Program Studi Ilmu Komunikasi UMY, selama satu semester genap tahun akademik 2020/2021 yang menghasilkan luaran berupa artikel ini.

\section{REFERENSI}

Aisyah, N. (2014). Relasi Gender dalam Institusi Keluarga. Muwazah, 5(2), 32-54.

Alva Orlandini, H. (2003). Bibioteca Hombres del Perú. Vol. 1. https://books.google.com.pe/books?id=iOJyAiS2gGoC\&dq

Frith, S., and Gates, H. L. (2010). A Dictionary of Critical Theory. In A Dictionary of Critical Theory. https://doi.org/10.1093/acref/9780199532919.001.0001

Hartley, J. (2003). A short history of social investigations. A Short History of Cultural Studies, 1189. https://doi.org/10.4135/9781446216934

Jihad, S. (2019). Fitrah Seorang Perempuan Terhadap Karir, Rumah Tangga Dan Pendidikan. AnNisa, 11(1), 324-334. https://doi.org/10.30863/an.v11i1.299

Keras, P., \& Curhat, D. A. N. (2006). 474 Commonline Departemen Komunikasi| Vol. 3/ No. 3. 3(3), 474-487.

Lady, I., Prastiwi, R., Rahmadanik, D., Pumpungan, M., \& Surabaya, K. (2020). Polemik dalam Karir Perempuan Indonesia. Komunikasi Dan Kajian Media, 4(45), 1-11. didarahma@untagsby.ac.id 2

Laughey, D. (2007). Key subjects in media hypothesis. Key Themes in Media Theory, 1-29.

Mansyur, A., \& Hidayat, D. (2020). Analisis Kebutuhan Wanita Karir Di Bidang Pendidikan Era Millenial. Psikologi Konseling, 17(2), 695. https://doi.org/10.24114/konseling.v $17 i 2.22072$

Uses, T. (2012). The Uses of Cultural Studies: A Textbook. In The Uses of Cultural Studies: A Textbook. https://doi.org/10.4135/9781446212318

Utamidewi, W. (2017). Konstruksi Makna Istri tentang Peran Suami. Jurnal Politikom Indonesiana, 2(2), 63-70.

Williams, K. (2003). Understanding Media Theory. 266.

Wuisan, V. E., Hairunnisa, \& Sabiruddin. (2018). Pengaruh Iklan Teh Sariwangi "Berani Bicara" Terhadap Keputusan Konsumen Dalam Membeli Pada Masyarakat Kecamatan Samarinda Ulu Di Kota Samarinda (Vike Enggelina Wuisan ,Hairunnisa,Sabiruddin). Jurnal Dunia Komunikasi, 6(4), 55-67. https://ejournal.ilkom.fisip-unmul.ac.id/site/?p=3638 